physies (44); biophysics of polysaccharides and nucleic acids (29); nervous system and muscles (60); biomechanics (8); teaching of biophysics and medical physics (6); virus and bacteriophages (14); immunology and bacteria (14); blood and body fluids (18); techniques (28). The invited papers presented at the four main sessions were published as a supplement to the Biophysical Journal (United States) and also in translation in the corresponding journals in the U.S.S.R. and Japan. Tho contributed papers were published by the authors in due course in journals of their own choice. However, some copies of a booklet (issued at the time of the Congress) containing summaries of all the contributed papers are still available for purchase from the secretary of the Stockholm Congress, Dr. B. Lindström, Karolinska Institutet, Stockholm, 60.

The general assembly of delegates to consider the proposals of the Steering Committee and of the Statutes Committee for an International Organization for Pure and Applied Biophysics was held on August 2. With minor modifications, the proposed statutes were approved and the delegates from 26 countries signified their wish to adhere to the new organization. Prof. A. Engström, of the Karolinska Institute, Sweden, was elected president, and Prof. A. K. Solomon, of Harvard Medical School, was elected secretary-general. There aro also two vicepresidents and twelve ordinary members of the Council which will act as the governing body of the new organiza. tion.

The question may be asked why the International Organization for Pure and Applied Biophysics (IOPAB) does not adhere to the International Council of Scientific Unions (ICSU). The immediate answer is that any international organization which wishes to become part of ICSU must exist for a minimum period of six years before any application for membership can be approved. In fact, the statutes of the new organization are very similar to those of some of the existing unions within ICSU, and IOPAB has statutory powers to adhere to ICSU at some future time. It already has excellent relations with two of the existing Unions (Physiology and Biochemistry) and joint committees have been set up with these two Unions for the discussion of problems of mutual interest. The structure of IOPAB resembles most closely that of the International Union of Pure and Applied Physics in that it will consist of a number of special commissions (which will take responsibility for the various branches of biophysics) together with affiliated commissions. The purpose of the latter is to permit the adherence of existing international groups in the field of biophysics, for example, medical physics. The affiliated commissions will be virtually autonomous in the same way as the International Commission for Optics operates in association with the Union for Pure and Applied Physics.

In a rapidly growing field of science which has rather vague boundaries, there is a great danger that too many 'international' conferences are organized in a free-lance and completely unco-ordinated manner. One of the greatest benefits which the new organization could bring to the workers in biophysics would be to plan and organize a limited number of first-class conferences at suitable intervals in appropriate countries. It is highly significant that the attendance at the first international conference at Stockholm was nearly 1,000. Many scientists feel that this number may already be too large and the undoubted success of the Stockholm conference was due in large measure to the superb organization by the Swedish hosts. A second general assembly of delegates is being planned for Paris in 1964 in conjunction with general lectures and meetings of the Commission on Cell and Membrane Biophysies and the Commission on Biophysics of Communication and Control Processes. The general assembly will consider the future pattern of meetings and the desirability of a second general Congress covering most of Biophysics in 1966 or 1967. The Commission on Molecular Biophysics (in co-operation with the Long Island Biological Association) is holding its first meeting at Cold Spring Harbor, Long Island, United States, this month.

\title{
OBITUARIES
}

\section{Prof. Rex Knight}

Prof. Rex Knight, who died on March 12 at the age of fifty-nine, was respected not only in his own profession and by his university colleagues, but also by generations of students who had come under his influence and had emerged better men and women as a result.

He was born in Australia and studied at the University of Sydney, graduating from there in 1923, after a brilliant undergraduate career, with first-class honours in philosophy. He followed this with a first in the Moral Sciences Tripos at Cambridge, where he was Hooper Prizeman in 1925. In that year he began his long association with the field of applied psychology, when he joined the National Institute of Industrial Psychology as assistant to the director. In 1928 he started his academic career as lecturer in psychology and philosophy in the University of St. Andrews, but only a year later he was appointed Anderson lecturer in psychology in Aberdeen where, apart from a war-time appointment in the War Office, he remained until his death, first as lecturer, then as reader and finally as professor.

Although his contributions to psychology and especially to applied psychology are numerous and varied, perhaps his greatest was to persuade people, particularly in the early days, when psychology was viewed with considerable mistrust, that psychology was a reasonable science, that it could contribute to the solution of problems in everyday life and work, and that psychologists were not just a collection of cranks. In his own person, with his sane, balanced and happy personality, Rex Knight was the best possible advertisement for his profession, and it is largely because of him that in the north-cast of Scotland, where his influence was felt most, relations between psychology on one hand, and education, medicine and industry on the other, enjoy a harmony that is the envy of many other parts of the United Kingdom.

Prof. Knight's gifts as a speaker were outstanding. His lectures were a model for their clarity of exposition, for the enthusiasm they generatcd, and for the efficiency with which they were presented. He had a profound respect for the English language: he himself used words, whether written or spoken, with the utmost care and precision, and he disliked the shoddy use of them by others.

As a public speaker, he was continually in demand, and he gave his services unstintingly. During the Second World War, from 1940 until 1943, ho gave, on behalf of the Ministry of Information, a series of brilliant war commentaries, which invariably drew capacity audiences. He took pains to master his subject completely, and then to present it skilfully, vitally and lucidly. These same qualities he brought to his work as an administrator. Whether as the head of a department, chairman of a mocting, or member of $\mathrm{a}$ committee, he was always well informed about the matter under discussion, and his contributions were invariably effective. He had the knack, when an involved discussion appeared to be thoroughly bogged down, of being able to sum up the 
arguments in the problem with detachment and clarity, so that a rational decision appeared possible once more. As a chairman, he was superb.

In recent years, he was much in demand as an expert in industrial psychology, who could make his subject appeal to audiences at all levels. He made outstanding contributions to the conferences held over a number of years by the National Coal Board at Oxford, and to the apprentices' conferences held since 1950 by the Industrial Welfare Society at Keble College.

As a person, he was happily extroverted and completely unselfconscious. He had a great affection for people, and took a deep and genuine interest in the academic progress, personal problems and later careers of hundreds of students who passed through his hands. He was sympathetic without being sentimental, he helped them to tackle their problems objectively and realistically, and men and women all over the world have reason to be grateful for his patience, his kindness and his wisdom.

Erizabeth D. Fraser

\section{Prof. W. E. Tröger}

Prof. Walter Ehrenreich Tröger, the distinguished German mineralogist and petrologist, died in Freiburg im Breisgau on January 13.

Born in Dresden on January 19, 1901, he studied mining and mineralogy in the Mining Academy of Freiberg in Saxony, an institution famous in the history of geology. From this Academy he graduated in 1924 with a degree in mining engineering. Another four years of study in the Dresden Technical High School culminated in a degree of Doctor of Engineering in 1928. In 1937 he became extraordinary professor of mineralogy at the University of Dresden, and from 1948 until 1952 he held a similar post at the Mining Academy of Clausthal, in 1952 extraordinary professor at the Technical High School in Darmstadt, and finally, in 1956, professor of mineralogy, petrology and ore deposits in the University of Freiburg im Breisgau.

Both the Darmstadt and the Freiburg mineralogical institutes had been greatly damaged during the War, and a great part of Tröger's time was spent in supervising the rebuilding of these institutions and in restoring and rearranging the collections, a difficult and laborious task which he carried out with great success. This work naturally cut into his time for his own research. This covered a wide field of mineralogy, petrology and ore deposits, first in his native Saxony and then in Odenwald and Harz. He described a number of minerals and igneous rocks and he gave the name 'bebedourite' to a variety of biotite-jacupirangite from Brazil. A characteristic feature of Tröger's writing was his terseness and precision, which are most clearly manifest in his two excellent and useful books.

One of these books is a tabular and diagrammatic representation of data relating to rock-forming minerals, the first edition of which was published in 1952, and the second in 1956. In this book the data are presented almost entirely in tabular form supported by numerous figures of crystals and various diagrams and projections.

The other book, much used by petrologists throughout the world, is entitled: Spezielle Petrographie der Eruptivgesteine: Ein Nomenklatur-Kompendium. It was published by the German Mineralogical Society in 1935 and the same Society published a supplement entitled Eruptiv. gesteinsnamen (1 Nachtrag) in 1938. The original book contains names and data relating to 777 species of igneous rocks and a list of 345 group-names, synonyms, 'stillborn' and obsolete rock-names. The supplement adds 140 new rock names, producing a total of 917 names of igneous rock species. Each of these species is given with concise information comprising the following items: author, reference, type locality, mineral composition, chemical composition, Niggli values, CIPW symbol, colour ratio, synonyms and varieties. The rocks are classified according to the two main variables-silica percentage and alkali percentage. It is most unfortunate that copies of this book are no longer obtainable, for the entire stock was destroyed during the War and Tröger himself was using the only remaining single copy left in the departmental library of his Institute. During the last years of his life Tröger was busy amplifying and revising this book for a projected new edition, but his premature death has left it unfinished.

Tröger was an excellent organizer, a perfect field geologist and an excellent teacher. He possessed a most charming personality and acted as a kind host to the numerous geologists of many nationalities who came to Freiburg im Breisgau in order to examine the two 'star' geological localities in its neighbourhood: Kaiserstuhl and Schwarzwald.

'Tröger's death, at the early age of 62 , is a loss not only to science but also to the many scientists who, having met him, could appreciate him as a personality apart from his writings.

S. I. TOMKEIEFF

\section{Dr. Lyman J. Briggs}

Dr. Lyman J. Briggs, director emeritus of the National Bureau of Standards, U.S. Department of Commerce and chairman emeritus of the Committee for Research and Exploration at the National Geographic Society, died on March 25. He was eighty-eight years old.

Dr. Briggs began his career in the Federal Service in 1895 as a physicist in the U.S. Department of Agriculture. During this period, he made historic contributions in the application of physics to agriculture, and organized what is now known as the Bureau of Plant Industry.

With the outbreak of the First World War, Dr. Briggs was assigned by executive order to work on war problems at the National Bureau of Standards. At the conclusion of the War, he stayed on and soon became chief of the Mechanics and Sound Division. In association with Paul R. Heyl, he invented the earth inductor compass, which later guided Lindbergh on his first trans-Atlantic flight. For this device, they received the Magellan Medal of the A.merican Philosophical Society in 1922.

His interests in aerodynamics resulted in pioneer measurements of flow around aeroplane wings at very high speeds up to and exceeding the speed of sound. Much of this work was done in association with Hugh L. Dryden, now deputy administrator of the National Aeronautics and Space Administration.

In July 1932, Dr. Briggs was appointed acting director of the National Bureau of Standards. Although the Bureau's operating funds were almost immediately cut in half in an economy measure, he was able to guide the laboratory through the depression period while preserving nearly two-thirds of the career employees in a working organization.

With the advent of the Second World War, Dr. Briggs directed that almost 90 per cent of the staff be assigned to work on problems of national defence. This work later resulted in such developments as the radio proximity fuse, improved optical glass, and the Bat guided missile.

In 1939, Dr. Briggs was asked by President Roosevelt to head and organize a secret investigation of the possibility of utilizing energy of atomic fission of uranium. Two years later this committee became section $S-1$ of the Office of Scientific Research and Development with Dr. Briggs as chairman and Profs. H. C. Urey, E. O. Lawrence, J. B. Conant, E. O. Murphee and A. H. Compton making up the executive committee. Much of the early work on the methods of purification of uranium, establishment of specific properties, and separation of isotopes of uranium was done at the Bureau under Dr. Briggs's direction with the assistance of distinguished guest workers.

Dr. Briggs officially retired from the Bureau in October 1945 although he continued to pursue his research interests 